\title{
Section XIII: Search and Rescue
}

\author{
Rule 107 \\ For the purposes of this Manual, "Shipwrecked" means persons, whether \\ military or civilian, who are in peril at sea or in other waters during an \\ armed conflict as a result of misfortune affecting them or the vessel, aircraft, \\ or spacecraft carrying them.
}

\section{Commentary}

1. This definition draws from Article 12 of GC/II and Article 8(b) of AP/I but clarifies that spacecraft can also yield a shipwreck situation. It must be taken into account that the AP/I definition (which includes all civilians and all types of waters) is not binding on non-contracting Parties. Moreover, there is not yet enough State practice related to the status of former occupants of spacecraft.

2. Although the crews of neutral aircraft or ships are not included in the list of protected persons under Article 13 of the GC/II, the Group of Experts agreed that the term shipwrecked also applies to them. This is true, in particular, if their vessel, aircraft or spacecraft has been attacked.

3. An individual who is without vessel, aircraft, or spacecraft at sea or other waters should be presumed to be at peril unless there is contrary information indicating the individual is at sea or other waters by choice. For example, an individual who chooses to swim into the water to avoid a land-based attack is not hors de combat due to shipwreck. Neither are the members of a water-borne combat unit who have entered the water voluntarily.

4. "Shipwrecked" are military or civilian persons in a perilous situation at sea or on any other waters following a misfortune and who refrain from all acts of hostility. See Rule 108.

5. Under Article 8(b) of AP/I the concept is expanded to include persons, who are in peril at sea or in other waters (e.g. lakes). The term "shipwreck" means 
shipwreck from any cause and includes forced landings at sea by or from aircraft (first paragraph of Article 12 of GC/II).

6. There is no evidence in general State practice to the effect that persons can reach a coast and nevertheless remain "shipwrecked" although such position has been taken by some.

\section{Rule 108}

Shipwrecked and other persons hors de combat are protected from attack, provided that they abstain from any hostile act and no attempt is made to evade capture or escape.

\section{Commentary}

1. This Rule is derived from Article 41 of AP/I. See also Article 23(c) of the 1907 Hague Regulations and Article 3 of GC/II.

2. For this context, there are two categories of persons hors de combat:

a. Those who have clearly expressed an intention to surrender; and

b. Those who are incapacitated. This latter category falls into three subsets: sick; wounded; and shipwrecked.

Upon due consideration, the majority of the Group of Experts decided not to retain the separate category of Article 41(a) of AP/I, i.e. persons "in the power of an adverse Party", in view of the fact that such category is irrelevant for the purpose of the present Section.

3. Note that clearly expressing an intention to surrender indicates more than mere desire to do so. See chapter "Section XII: Surrender".

4. Although, as a term of art, the expression "hors de combat" is reserved for combatants, for the purposes of this Rule the concept covers incapacitation of both combatants and civilians who have directly participated in hostilities since the latter will, by definition, no longer be participating in hostilities when hors de combat.

5. The presumption of hors de combat status for an individual at sea or other waters during an armed conflict is rebutted if he or she commits a hostile act, or attempts to escape or evade capture.

6. The status of hors de combat, including that of "shipwrecked", applies both in international and in non-international armed conflict.

7. Although Article 41(2) of AP/I conditions hors de combat status on the absence of an "attempt to escape" the Group of Experts decided that in case of shipwreck the condition must be extended so that no attempt to evade capture is made.

\section{Rule 109}

(a) Persons parachuting from an aircraft in distress may not be made the object of attack during their descent unless they engage in hostile acts.

(b) Upon reaching the ground in territory controlled by the adverse party the parachutists from an aircraft in distress shall be given an opportunity 
to surrender, unless it is apparent that they are engaging in a hostile act or attempting to evade capture.

(c) Airborne troops are not protected by this Rule.

\section{Commentary}

1. This provision is based on Article 42 of AP/I.

2. Although not expressly referred to by AP/I as hors de combat, parachutists from aircraft in distress may be assimilated to that status during their descent, unless they engage in hostile acts.

3. The assumption is that upon landing in a territory controlled by the enemy the parachutist from the aircraft in distress will surrender. The enemy must provide him/her with an opportunity to do so.

\section{Rule 110}

A person who is hors de combat remains as such until the circumstances that gave rise to that status are altered.

\section{Commentary}

1. Whether an individual is hors de combat depends on facts and is based on the circumstances ruling at the time.

2. An individual can be hors de combat for a particular reason, may thereafter lose that status as a result of a change in the circumstances that rendered him/her hors de combat, but may then become hors de combat for another reason. For example, a shipwrecked individual may be rescued-in which case he/she is no longer hors de combat by reason of shipwreck—but may also be wounded thus acquiring the status of hors de combat due to injury.

3. An individual who is hors de combat is not a lawful target, regardless of the reason why he or she is hors de combat.

4. It goes without saying that anyone who engages in hostile acts can no longer be protected as hors de combat.

\section{Rule 111}

(a) A shipwrecked combatant remains hors de combat during rescue provided he or she refrains from all acts of hostility.

\section{Commentary}

1. If someone is hors de combat due to shipwreck, he/she will be considered hors de combat due to shipwreck throughout a rescue.

2. This Rule is consistent with the definition of "shipwrecked" found in Rule 107.

(b) "During rescue" means the time during which a shipwrecked individual is in the process of being rescued from sea or other waters. This includes 
the time during which the person is being assisted onto land, or into an aircraft, a vessel or another conveyance.

\section{Commentary}

1. This Rule is consistent with the definition of "shipwrecked" found in Rule 107 and Article 8 (b) of AP/I. It is designed to clarify that point during a rescue operation at which a shipwrecked individual might regain combatant status. See also, Rule 112 and its Commentary.

\section{Rule 112}

A combatant or other person, after being rescued and transported onto land, or into an aircraft, a vessel or another conveyance capable of transportation to a safe location, is no longer hors de combat by reason of being shipwrecked.

\section{Commentary}

1. The precise moment when a rescue concludes, thus terminating an individual's hors de combat status by reason of shipwreck, depends on the circumstances. Generally, it includes the time during which the individual is being lifted into a helicopter or a vessel designed for normal conveyance of personnel.

2. The requirement that the ultimate conveyance that triggers the termination of hors de combat status be "capable of transportation to a safe location" is meant to exclude life boats and other vessels designed to preserve life but not provide transportation to safety. The conveyance need not be designed specifically to carry passengers, such as a ferry, but it has to be seaworthy or otherwise capable of transport in the conditions prevailing at the time.

3. By way of example, shipwrecked individuals are hors de combat while being lifted into a rescuing helicopter but are no longer hors de combat upon reaching the helicopter. Conversely, shipwrecked individuals being lifted into an emergency life boat remain hors de combat until ultimately rescued from the lifeboat and moved onto a conveyance capable of carrying them to land or otherwise removing them from peril.

4. Once a rescue is complete, the individuals are no longer hors de combat due to shipwreck. However, they may become hors de combat for another reason. See Commentary to Rule 110.

\section{Rule 113}

The conduct of search and rescue operations does not cause military aircraft, vessels or other conveyances, or military personnel conducting the operations, to be protected from attack, regardless of whether the person being rescued is civilian or military. 


\section{Commentary}

1. The status of military personnel and of military conveyances as lawful targets does not change due to the mere fact that they are engaged in search and rescue operations, whether for the benefit of either combatant or civilian shipwrecked.

2. Even if the persons who are the object of rescue are hors de combat by reason of shipwreck, their protected status does not (i) extend to the military personnel or the military conveyances searching for or rescuing them; or (ii) endure after they have been lifted to the aircraft or vessel and are no longer in water.

3. A separate issue arises with regard to persons who remain hors de combat due to being wounded. Regardless of whether they continue to be protected after having been lifted to an aircraft or vessel, the status of the vehicle as a lawful target remains unchanged. Whether an attack on the vehicle is consistent with LOAC is subject to proportionality and precautions in attack, if the persons rescued are civilians.

\section{Rule 114}

(a) "Combat Search and Rescue (CSAR) operations" enjoy no protection from attack.

(b) "CSAR operations" means the rescue, or attempted rescue, of combatants in distress, whether at sea, on land, or in Outer Space, when the rescue or attempted rescue occurs during an armed conflict and is carried out by combatants.

\section{Commentary}

1. If a search-and-rescue operation is conducted during armed conflict by military personnel or conveyances, for the benefit of combatants in distress, then it is a combat search-and-rescue operation (CSAR). Such an operation enjoys no protection from attack. Similarly, if the rescued persons were civilians in distress, the rescuers and the operation itself would not enjoy protection even if the shipwrecked persons being rescued would.

2. See Commentary to Rule 113 regarding the propriety of including wounded individuals in proportionality analyses.

\section{Rule 115}

(a) Medical aircraft lose their specially protected status if they engage in conduct inconsistent with the requirements of that status.

(b) Such inconsistent activities include CSAR operations.

\section{Commentary}

1. Medical aircraft, that is to say, aircraft exclusively employed for the removal of wounded and sick and for the transport of medical personnel and 
equipment, ${ }^{1}$ enjoy specially protected status within the scope of Articles 36 and 37 of GC/I, Articles 25-31 of AP/I and customary LOAC.

2. Under GC/I, the specially protected status of medical aircraft is dependent on the location of the medical aircraft and on, when so required, a prior agreement between the parties to the conflict. ${ }^{2}$

3. Even if there is a valid reason for discontinuing the specific protection of medical units or medical transports, a warning must be issued first. ${ }^{3}$ The warning may take various forms. In many instances, it can simply consist of an order to cease the harmful act within a specified period. The time-limit must be reasonable in order to give an opportunity for the unlawful acts to be stopped or to allow removal to a place of safety of the wounded and sick within the medical units or medical transports, prior to any attack. In some cases, it may be reasonable to insist on immediate compliance with a warning. However, even in these cases, the principle of proportionality and the requirement to take feasible precautions in attack apply. Medical aircraft do not become lawful targets unless the warning remains unheeded. 4

4. Paragraph 3 of this commentary is without prejudice to the exceptional circumstance of a medical aircraft engaging in attack, in which case a warning may become redundant when self-defence measures are resorted to.

5. In the absence of a specific agreement between parties to an armed conflict, medical aircraft should refrain from conducting search-and-rescue operations because it may lead to the conclusion that they are engaging in combat operations. For that reason, this Rule clarifies that if these medical aircraft engage in searchand-rescue operations they lose their protection. However, this Rule notes the requirement that any attacker give the medical aircraft a warning and a reasonable time-limit to heed that warning.

\section{Rule 116}

Hospital ships and coastal rescue craft lose their specially protected status if they engage in conduct inconsistent with the conditions of their protection and if the requirements of the law of naval warfare are met.

\section{Commentary}

1. Hospital ships, that is to say, ships built or equipped specially and solely with a view to assisting the wounded, sick and shipwrecked, to treating them and to transporting them, ${ }^{5}$ and coastal rescue craft, i.e. craft employed by the State or

\footnotetext{
${ }^{1}$ GC/I, see chapter "Section I: Outer Space", fn. 19, Article 36.

${ }^{2}$ AP/I, see chapter "Section I: Outer Space", fn. 13, Articles 25-27. AMW Manual, see chapter "Section I: Outer Space", fn. 1, Rules 77 and 78.

${ }^{3} A M W$ Manual, ibid, Rule 38.

${ }^{4}$ GC/I, see chapter "Section I: Outer Space", fn. 19, Article 21.

${ }^{5} \mathrm{GC} / \mathrm{II}$, ibid, Article 22 .
} 
by the officially recognized lifeboat institutions for coastal rescue operations, ${ }^{6}$ enjoy special protection in accordance with Article 34 of GC/II and Article 22 of AP/I. This means that hospital ships as well as coastal rescue craft may be neither attacked nor captured.

2. Non-compliance with the conditions of their protection as laid down in Article 30 of the GC/II will usually render hospital ships and coastal rescue craft liable to capture. However, if they commit "acts harmful to the enemy" they will become liable to attack subject to the requirements set out in paragraph 3.

3. Hospital ships and coastal rescue craft committing acts harmful to the enemy may be made the object of an attack only after a due warning has been given, naming in all appropriate cases a time limit, and after such warning has remained unheeded. ${ }^{7}$ Acts not amounting to acts harmful to the enemy are listed in Article 35 of GC/II. However, in so far as the use of secret codes for communications systems is concerned, see the position taken in the San Remo Manual paragraph 171 as to subsequent practice. ${ }^{8}$ The text of GCII, which governs the use of hospital ships, does not make it clear whether such a vessel can itself indulge in rescue operations or, alternatively, it merely transports and treats those rescued by other craft.

4. It is important to note that hospital ships are entitled to additional protections under LOAC that are not accorded to coastal rescue craft. This is illustrated in Article 27 of GC/II, which states that "[u]nder the same conditions as those provided for in Articles 22 and 24 [referring to hospital ships], small craft employed by the State or by the officially recognized lifeboat institutions for coastal rescue operations, shall also be respected and protected, so far as operational requirements permit."

5. The San Remo Manual's assessment of customary international law, besides confirming in Rule 49 that hospital ships must be warned that their exemption from attack is endangered and cannot be targeted unless they do not heed the warning, specifically states that hospital ships can be targeted only "as a last resort." The San Remo Manual does not articulate a requirement that coastal rescue craft be given a warning or that they be attacked only "as a last resort.",

\section{Rule 117}

Non-military aircraft other than medical aircraft, and non-naval vessels other than hospital ships and coastal rescue craft, which are engaged in search and rescue operations, may not be attacked unless they:

\footnotetext{
${ }^{6} \mathrm{GC} / \mathrm{II}$, ibid, Article 27.

${ }^{7} \mathrm{GC} / \mathrm{II}$, ibid, Article 34 .

${ }^{8}$ See as well US DoD Manual, chapter "Section II: Cyber Operations", fn. 4, para 7.12.2.7.

${ }^{9}$ San Remo Manual, see chapter "Section II: Cyber Operations", fn. 4, para 51.

${ }^{10}$ San Remo Manual, ibid, para 52.
} 
(a) Assist a rescued enemy combatant, or other person liable to capture, to escape or evade capture;

\section{Commentary}

1. Civilians engaged in efforts to return combatants to the battlefield are directly participating in hostilities (see chapter "Section VII: Civilians Directly Participating in Hostilities") and thus no longer protected against attack.

(b) Refuse a demand to surrender an enemy rescued combatant; or

\section{Commentary}

1. A refusal to surrender an enemy rescued combatant may also amount to direct participation in hostilities.

(c) Otherwise make an effective contribution to the enemy's military action.

\section{Commentary}

1. The Rule in (c) serves as a reminder that objects may become lawful targets by conduct not covered in (a) or (b), such as the transmission of military intelligence to the enemy.

\section{Rule 118}

The Rules of this Section are without prejudice to the right of the parties to the conflict to enter into agreements on the protection of aircraft, vessels or other vehicles employed for search and rescue.

\section{Commentary}

1. This Rule reflects the principle that parties to the conflict may always agree on the creation of additional protections that are not required by LOAC, and that search and rescue operations represent an understandable area for such additional protections. $^{11}$

\footnotetext{
${ }^{11}$ See for example, AP/I, chapter "Section I: Outer Space”, fn. 13, Article 26 (1) and 27 and 28 (4).
} 
Open Access This chapter is licensed under the terms of the Creative Commons Attribution 4.0 International License (http://creativecommons.org/licenses/by/4.0/), which permits use, sharing, adaptation, distribution and reproduction in any medium or format, as long as you give appropriate credit to the original author(s) and the source, provide a link to the Creative Commons licence and indicate if changes were made.

The images or other third party material in this chapter are included in the chapter's Creative Commons licence, unless indicated otherwise in a credit line to the material. If material is not included in the chapter's Creative Commons licence and your intended use is not permitted by statutory regulation or exceeds the permitted use, you will need to obtain permission directly from the copyright holder. 